\title{
The taxonomic placement and provenance of Hypopyra inconspicua Herrich-Schäffer (Lepidoptera, Thyrididae)
}

\author{
Vitor O. Becker ${ }^{1}$ \\ ${ }^{1}$ Reserva Serra Bonita, P. O. Box 01, 45880-970 Camacan-BA, Brazil. becker.vitor@gmail.com
}

\begin{abstract}
The taxonomic placement and provenance of Hypopyra inconspicua Herrich-Schäffer (Lepidoptera, Thyrididae). Tanyodes inconspicua (Herrich-Schäffer) comb. nov. is transferred from Spirama Guenée (Noctuidae, Catocalinae) to Striglininae (Thyrididae), as a senior synonym of Ortogramma rufitibia R. Felder \& Rogenhofer syn. nov. and Tanyodes ochracea Möschler syn. nov., and from the African to the Neotropical fauna.
\end{abstract}

KEYWORDS. Africa; Neotropical; Noctuidae; synonymy; taxonomy.

RESUMO. Posição sistemática e procedência de Hypopyra inconspicua Herrich-Schäffer (Lepidoptera, Thyrididae). Tanyodes inconspicua (Herrich-Schäffer) comb. nov. é transferida de Spirama Guenée (Noctuidae, Catocalinae) para Striglininae (Thyrididae), como sinônimo mais antigo de Ortogramma rufitibia R. Felder \& Rogenhofer syn. nov. e Tanyodes ochracea Möschler syn. nov., e da fauna africana para a neotropical.

PALAVRAS CHAVE. África; Neotropical; Noctuidae; sinonímia; taxonomia.

Hypopyra inconspicua was described by Herrich-Schäffer ([1854]; in the "Noctuina" based on an unspecified number of specimens from "Cap." [Cape Town, S. Africa]. It was listed by Hampson (1913: 334) in the Catocalinae (Noctuidae) among the "Species Omitted" and transferred by Poole (1989) to Spirama Guenée in the same subfamily. Häuser et al. (2003) found and illustrated in colour, two [female] syntypes in the Staatlisches Museum für Naturkunde, Stuttgart, Germany (SMNS), both labeled "Surinam, Kpl.". According to the original illustrations and to those presented by the latter authors, there is no doubt that they represent a Striglininae (Thyrididae) species described twice again from Brazil and Surinam, proving that the syntypes labels are correct, and the type locality wrong. The species seems not rare as Whalley (1976: 130), who monographed the subfamily, studied 55 specimens ranging from the Guianas to Peru, deposited in the Natural History Museum, London (BMNH). In the author's collection (VOB) there is a series of nine specimens collected in the Brazilian states of Maranhão, Pará and Rondônia. The full synonymy of the species is presented below.

\section{Tanyodes inconspicua (Herrich-Schäffer) comb. nov.}

Hypopyra inconspicua Herrich-Schäffer, [1854]: pl. [26]: figs. 123, 124, wrapper; [1858]: 68, 79. Two ợ syntypes, SURINAM: [no further data], ( 'Kpl.") (SMNS), colour illustrations examined [Häuser, Bartsch, Holstein and Steiner, 2003: 50, 64, fig. 48.]
Orthogramma rufitibia R. Felder \& Rogenhofer, 1874, pl. 117, fig. 1. Holotype ơ, BRAZIL: [no further data] [Amazons] (BMNH), colour illustration examined. Syn. nov.

Tanyodes ochracea Möschler, 1882: 415. Holotype o, SURINAM: [no further data] (MNHU), examined and synonymized under T. rufitibia by Whalley (1976: 129). Syn. nov.

Tanyodes rufitibia; Whalley, 1976: 129, pl. 10, figs. 94-95.

Spirama inconspicua; Poole, 1989: 921.

Remarks. Tanyodes is a monotypic genus, and its type species, T. ochracea, was synonymized under T. rufitibia by Whalley (1976: 129), a species originally described as a Noctuidae, but transferred to the Siculidae (=Thyrididae) by Guenée (1877: 286).

\section{ACKNOWLEDGEMENT}

Dr. Anthony Raw, Universidade Estadual de Santa Cruz (UESC), Ilhéus, Bahia, corrected the manuscript.

\section{REFERENCES}

Felder, C., Felder, R. \& A. F. Rogenhofer. 1874. Reise Osterreichischen Fregatte Novara. Zoologischer Theil. II (2). Wien, Carl Gerold's Sohn. Pls 75-120.

Guenée, A. 1877. Ébauche d'une monographie de la famille Siculides. Annales de la Société Entomologique de France 7: 275-304.

Hampson, G. 1913. Catalogue of the Lepidoptera Phalaenae in the British Museum, v. 13. London, British Museum, 609 p. 
Häuser, C. L., Bartsch, D., Holstein, J. and Steiner, A. 2003. The Lepidoptera type material of G. A. W. Herrich-Schäffer in the Staatliches Museum für Naturkunde, Stuttgart. Sttutgarter Beiträge zur Naturkunde, Serie A (Biologie), 657: 1-78.

Herrich-Schäffer, G. A. W. [1850-1858]. Sammlung neuer oder weniger bekannter ausseuropäischer Schmetterlinge. Regensburg, Manz, 84 p.
Möschler, H. B. 1882. Beiträge zur Schmetterlings-Fauna von Surinam. Verhandlungen der Keiserlich-Königlischen Zoologisch-Botanischen Gesellschaft in Vien 31: 393-442.

Poole, R. W. 1989. Noctuidae. Lepidopterorum catalogus 118: 501-1013. Whalley, P. E. S. 1976. Tropical leaf moths. London, British Museum (Natural History), $194 \mathrm{p}$.

Received 2/7/2010; accepted 6/1/2011

Editor: Marcelo Duarte 